\title{
Removal of aqueous Clopyralid by Photoctalytic-ozonation process on Activated carbon under solar radiation: Catalyst characterization and kinetic study
}

\author{
Zouhour Rajah ${ }^{1, *}$, Monia Guiza ${ }^{1}$, Francisco Javier Rivas Toledo ${ }^{2,3}$, Abdelmottaleb Ouederni $^{1}$ \\ ${ }^{1}$ Research Laboratory Process Engineering and Industrial Systems, National School of Engineers of Gabes, University of Gabes, Street \\ Omar Ibn El Khattab, 6029 Gabes, Tunisia \\ ${ }^{2}$ Departamento de Ingeniería Química y Química Física, Universidad de Extremadura, 06071 Badajoz, Spain \\ ${ }^{3}$ Instituto de Universitario del Agua, Cambio Climático y Sostenibilidad (IACYS), Universidad de Extremadura, Avda. de la \\ Investigación s/n 06071 Badajoz, Spain
}

\begin{abstract}
Solar photocatalytic ozonation has been used to oxidize the herbicide clopyralid in aqueous solution. Activated carbon used as a catalyst was characterized by Scanning Electron Microscopy (SEM) images showed the presence of irregular cavities and pores, which have different sizes and shapes, with a great surface area of BETand a high pHpzc. The adsorption kinetics was found to follow the pseudosecond-order kinetic mode. Catalyst stability was tested by means of consecutive reuse cycles. After five cycle of reuse the adsorption efficiency reached $75 \%$ of the clopyralid removal.Clopyralid elimination kinetic by direct ozonation has been studies. The system $\mathrm{O}_{3} / \mathrm{AC} /$ Daylight significantly improves clopyralid and mineralization rate abatement if compared to runs conducted in the absence of radiation and/ or activated carbon. Clopyralid total abatement was achieved in less than $30 \mathrm{~min}$ when $0.5 \mathrm{~g} / \mathrm{L}$ of activated carbon and under solar radiation $(300-800 \mathrm{~nm})$ were used. Thus, TOC removal in 180 min treatments increased from 20 to about $90 \%$ in $\mathrm{O}_{3}$ and $\mathrm{O}_{3} / \mathrm{OSAC} /$ Daylight, respectively, under similar operating conditions.
\end{abstract}

\section{Introduction}

Currently, important attention has been given to the appearance of various pesticides in the aquatic environment as micropollutants, and in particular the herbicides. These discharges has a chemical stability, more recalcitrant to biological degradation and undesirable effects on non-targeted species [1,2]. There is many effective methods to eliminate their and transforming into products that are not harmful to the environment [3]. Clopyralid (3,6-dichloropyridine-2carboxylic acid, $\mathrm{C}_{6} \mathrm{H}_{3} \mathrm{C}_{12} \mathrm{NO}_{2}$ ) an organochlorinated compound $[4,5]$, which is one of the strong persistence herbicide and present a high solubility in water $[5,6]$. This compound has been used effectively for controlling annual and perennial broadleaf weeds in certain crops and turf [7]. It also provides effective control of certain brush species on rangeland and pastures [7, 8]. Clopyralid is one of the herbicides that are often detected in drinking water $[9,10]$.

Consequently, the elimination of this substance from water resources is very important. However, conventional treatment processes are not intentionally designed for the depletion of persistent organic pollutants, such as the herbicides, contained in wastewater [11]. Advanced Oxidation Processes (AOPs) are investigated to treat water containing these persistent organic pollutants [6, 12, 13]. These processes are physicochemical based on the formation of hydroxyl radicals, $\mathrm{HO}^{\circ}$ is highly reactive and unstable oxidizing species, which makes it able to mineralize almost any organic molecule $[12,14,15]$. That can be generated by different methods like chemical, electrochemical, and photochemical methods [13]. Ozonation wich is based on ozone has been the most widely used AOP. Compared to oxygen, ozone is a powerful oxidant specie, which can reacts with many organic compounds either through a direct reaction of molecular ozone or through a radical type reaction involving the hydroxyl radical $\left(\mathrm{OH}^{\circ}\right)$ generation induced by the ozone decomposition in water [16-18]. Therefore, single ozonation is not sufficient to achieve high mineralization degree. To overcome this drawback, ozonation processes are being modified in order to increase thiers oxidizing capability. The addition of homogeneous or heterogeneous catalysts during the ozonation is positive to rise the treatment efficiency of wastewaters. For catalytic ozonation process the frequently studied catalysts include activated carbon (AC). For aqueous ozone decomposition, activated carbon can acts as a free-radical initiator.

During the last years, combined technologies have attracted the scientific interest [4]. Given, the benefits and inconveniences of each technology, coupling processes appear as good alternative to produce better

*Corresponding author: rajah.zouhour90@gmail.com 
results [14, 19]. In this way, the combination of photodegradation and ozonation, hydrogen peroxide treatment and other advanced oxidation technologies is very attractive [20]. That, this combination is able to reach a high removal efficiency and reproduces no secondary pollution, and can generate a great amount of hydroxyl radical [21]. It should be noted that, photolysis and photocatalytic processes has been applied by using sunlight. This method is the major route of dissipation of herbicides in aquatic media [22, 23].

Based on the above-mentioned, the main aim of this work is to study various AOPs, such as ozonation, catalytic ozonation, photocatalytic ozonation and the combination of some of them have been applied to degrade clopyralid compound and processes performance have been compared. Furthermore, kinetic aspects were evaluated. Therefore, the feasibility of using activated carbon as an adsorbent for the elimination of clopyralid was evaluated and the applicability of various kinetic models, pseudo-first-order, pseudo-second-order and intraparticle diffusion models was tested.

\section{Experimental}

\subsection{Materials}

\subsubsection{Chemicals}

Commercial clopyralid was purchased from SigmaAldrich. Cliophar 425 from AGRIPHAR® (42.5\% in the amine salt of clopyralid) was used as received in all experiments.

\subsubsection{Preparation of catalyst}

The activated carbon was prepared from solid particles of olive stones by physical processes and crushed in the size range of $1.25-4.00 \mathrm{~mm}$. The method used was developed byNajar et al. [24]. Raw material of the activated carbon was cleaned and washed perfectly with hot distilled water to remove any leachable impurities. Thereafter, the olive stones were carbonized under a continuous nitrogen flow. The carbonization temperature was optimized to be $600^{\circ} \mathrm{C}$ and the time was fixed for two hours. The char obtained from the first step was then activated in the same furnace using water vapor as oxidizing agent at fixed temperature between $600^{\circ} \mathrm{C}$ and $800^{\circ} \mathrm{C}$ for $8 \mathrm{~h}$. Table 1 showed the elemental analysis of the stones. The high carbon and low ash contents make olive stone a good starting material in the production of porous activated carbons [24].

Table 1.Elemental analysis of olive stones [24]

\begin{tabular}{llllll}
\hline Element & C & H & O & N & Ash \\
\hline $\begin{array}{l}\text { Composition } \\
(\%)\end{array}$ & 47.3 & 6.1 & 44.66 & 0.075 & 1.86 \\
\hline
\end{tabular}

Textural characterization of olive stones activated carbon (OSAC) was carried out by $\mathrm{N} 2$ adsorption at $77 \mathrm{~K}$ using QuantachromeAutosorb automatic apparatus (iQ2-C Series). The Brunauer-Emmett-Teller (BET) is the most common standard procedure was applied to calculate the specific surface area. The estimation of total pore volume $\mathrm{V}_{\text {tot }}$ of the samples was done from the volume of adsorbed nitrogen gas at the maximum relative pressure close to $\mathrm{P} / \mathrm{P}_{0}=1$ (at 0.95 relative pressure). The estimation of micro and mesopore volumes $\left(\mathrm{V}_{\text {mic }}\right.$ and $\mathrm{V}_{\text {mes }}$ respectively) and the external surface area (Sext) were determined through t-method. The Density Functional Theory (DFT) was applied to analyze the pore size distribution (PSD).

Surface morphology and the pore structure of the activated carbon was imaged through Scanning Electron Microscopy (SEM) analysis.

In addition, the procedure described as follow was used to determine the point of zero charge pHpzc, $50 \mathrm{~mL}$ of solutions of containing $0.1 \mathrm{M} \mathrm{NaCl}$ solution were prepared and its $\mathrm{pH}\left(\mathrm{pH}_{\text {initial }}\right)$ was adjusted between 2 and 12 by the addition of a diluted solution $0.01 \mathrm{M}$ of either $\mathrm{NaOH}$ or $\mathrm{HCl}$. When the $\mathrm{pH}$ value was constant, $0.15 \mathrm{~g}$ of sample of dried OSAC and ozonated OSAC-O $\mathrm{O}_{3}$ was added to each solution with different $\mathrm{pH}$ solutions and it then shaken for $48 \mathrm{~h}$ and the final $\mathrm{pH}\left(\mathrm{pH}_{\text {final }}\right)$ of the solutions were measured. The pHpzc value was plotted according to the intersection point of the final $\mathrm{pH}$ versus the initial $\mathrm{pH}$ curve and the bisector gives the $\mathrm{pHpzc}$ value [25].

\subsection{Experimental setup and procedure}

The experimental reaction system (simple oxidation, catalytic ozonation and solar photcatalytic ozonation) were carried out in a glass reactor with a capacity of 500 mL.It was magnetically stirring in order to keep the reactor content perfectly mixed. The reactor was filled with $0.5 \mathrm{~L}$ of a clopyralid aqueous solution, and solid catalyst was initially added before starting the reaction.

In typical experiment, the gas flow rate used at $30 \mathrm{~L}$ $\mathrm{h}^{-1}$ of oxygen-ozone mixture, was continuously fed with a stream bubbled through the reactor generated by a Sander Laboratory Ozone Generator. The gaseous ozone concentration was monitored by an Anserosozomat ozone analyzer, the measurement based on the absorbance at $254 \mathrm{~nm}$. Additionally for solar photocatalytic ozonation experiments, clopyralid solution were placed in the reactor inside the chamber of the solar simulator using Suntest CPS+ apparatus from Atlas equipped with a $1500 \mathrm{~W}$ air-cooled Xenon arc Lamp (emitting radiation of wavelength in the range $300-800$ $\mathrm{nm})$. Samples at different times were extracted and filtered by means of Millex-HA filters (Millipore, 0.45 $1 \mathrm{~m})$ and bubbled with air in order to remove dissolved ozone when required before analysis. All experiments were conducted at the natural $\mathrm{pH}$ of the solutions, with no addition of buffering substances.

\subsection{Analysis}


Clopyralid concentrations were measured by Ultra-Flow Liquid Chromatography in a UFLC Shimadzu Prominence LC-AD with Diode Array detection. A thermally maintained at $30^{\circ} \mathrm{C}$ Core-shell $\mathrm{C} 18$ Kinetex ${ }^{\circledR}$ $(150 \times 4.6 \mathrm{~mm}, 5 \mu \mathrm{m})$ was used as stationary phase. The mobile phase was pumped at a flow rate of $1 \mathrm{~mL} \mathrm{~min}^{-1}$ using the acetonitrile: water $(0.1 \%$ phosphoric acid $)$ ratio equal to (20:80) injection volume of $100 \mu \mathrm{L}$. Detection was conducted at wavelength $225 \mathrm{~nm}$.Aqueous ozone concentration for different processes was determined following the Indigo method based on the discoloration of 5,5,7- indigotrisulfonate, spectrophotometrically determined at $600 \mathrm{~nm}$ by ozone. The $\mathrm{pH}$ of the reaction media was measured by means of a GLP $21+$ CRISON $\mathrm{pH}$ meter. In order to assess the degree of mineralization, Total Organic Carbon (TOC) was determined using a Shimazdu TOC- $\mathrm{V}_{\mathrm{CSH}}$ analyzer.

\subsection{Clopyralid adsorption test on Activated Carbon}

A series of adsorption experiments were performed in a standard-joint pyrex glass flasks. Different amount of OSAC $\left(0.1-1 \mathrm{~g} \mathrm{~L}^{-1}\right)$ were introduced within $500 \mathrm{~mL}$ of Clopyralid aqueous solution $\left(1 \mathrm{mg} \mathrm{L}^{-1}\right)$. The flasks were then stirred at $300 \mathrm{rpm}$ at $25^{\circ} \mathrm{C}$ and natural $\mathrm{pH}$. For different preset time intervals samples were filtered and residual clopyralid concentration in solution was determined by UFLC.

The adsorption efficiency ( $\mathrm{R} \%$ ) and adsorption capacity $\mathrm{q}_{\mathrm{t}}\left(\mathrm{mg} \mathrm{g}^{-1}\right)$ of clopyralid was evaluated by the following equations:

$$
\begin{gathered}
R \%=\frac{C_{0}-C_{t}}{C_{0}} \times 100 \% \\
q_{t}=\frac{\left(C_{0}-C_{t}\right)}{m} \times V
\end{gathered}
$$

Where $\mathrm{C}_{0}$ is the initial concentration of clopyralid in the solution $\left(\mathrm{mg} \mathrm{L}^{-1}\right), \mathrm{C}_{\mathrm{t}}$ is the concentration remaining in the solution, $\mathrm{m}$ is the mass of activated carbon used in a given volume of solution $(\mathrm{g}), \mathrm{q}_{\mathrm{t}}$ is the clopyralid uptake $\left(\mathrm{mg} \mathrm{g}^{-1}\right)$ and $\mathrm{V}$ is the volume of solution in the flask.

\section{Results and discussion}

\subsection{Catalyst characterization}

The textural properties of both virgin OSAC and ozonated $\mathrm{OSAC}-\mathrm{O}_{3}$ were determined by nitrogen adsorption and desorption isotherms at $77 \mathrm{~K}$ are given by Figure 1.A. For all samples isotherms appear to have a well-defined plateau that could be classified as Type IV according to the UIPAC classification [26]. The specific surface area and pore volumes were calculated by applying BET, the results of the textural properties are depicted in Table 2. Accordingly, high porosity of activated carbon produces a large surface area as seen from the BET analysis. This can be an advantage leading to the idea of catalytic ozone decomposition.

The investigation of point of zero charge (pHpzc) of the raw OSAC and $\mathrm{OSAC}-\mathrm{O}_{3}$ are determined and illustrated in Table 2. In present study the pHpzc of OSAC indicates its basic character, it can be seen that after attack with ozone, the pHpzc decreases depicting the acidification of surfaces related to the oxidation with ozone.

The investigation of the surface morphology of both materials of activated carbon before and after azonation by Scanning electron micrographs (Figure 1.B) shows the presence of irregular and well-developed cavities on the surface of carbon and shapes resulted from the influence of the activating agent, in this case is water vapor on the development of OSAC porosity. The virgin and ozonated catalyst analyzes show that both materials have relatively identical morphologies. The surface of the activated carbon appears to be slightly attacked by ozone, no major difference is observed after ozonation.

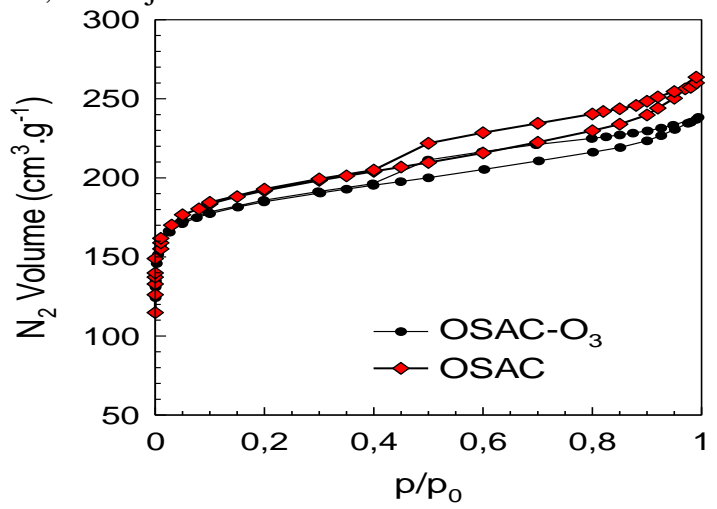

Fig. 1.A. Nitrogen adsorption-desorption isotherm of virgin OSAC and ozonated OSAC- $\mathrm{O}_{3}$.

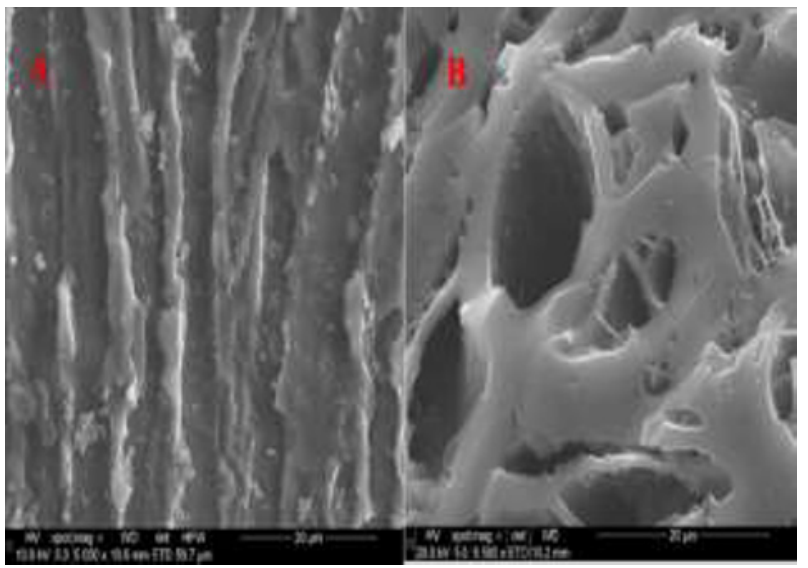

Fig. 1.B. SEM images of OSAC and OSAC-O 
Table 2. Textural properties and chemical composition of the catalysts.

\begin{tabular}{lllllllll}
\hline sample & $\begin{array}{l}\mathrm{S}_{\text {BET }} \\
\left(\mathrm{m}^{2} \cdot \mathrm{g}^{-1}\right)\end{array}$ & $\begin{array}{l}\mathrm{S}_{\text {micr }} \\
\left(\mathrm{m}^{2} \cdot \mathrm{g}^{-1}\right)\end{array}$ & $\begin{array}{l}\mathrm{V}_{\text {tot }} \\
\left(\mathrm{cm}^{3} \cdot \mathrm{g}^{-1}\right)\end{array}$ & $\begin{array}{l}\mathrm{V}_{\text {mic }} \\
\left(\mathrm{cm}^{3} \cdot \mathrm{g}^{-1}\right)\end{array}$ & $\begin{array}{l}\mathrm{V}_{\text {mes }} \\
\left(\mathrm{cm}^{3} \cdot \mathrm{g}^{-1}\right)\end{array}$ & $\begin{array}{l}\mathrm{S}_{\text {ext }} \\
\left(\mathrm{m}^{2} \cdot \mathrm{g}^{-1}\right)\end{array}$ & $\begin{array}{l}\mathrm{D}_{\mathrm{m}} \\
\left(\mathrm{A}^{\circ}\right)\end{array}$ & $\mathrm{pHpzc}$ \\
\hline OSAC & 734.17 & 614.23 & 0.407 & 0.34 & 0.06 & 109.42 & 22.2 & 10.5 \\
\hline OSAC-O $_{3}$ & 717.45 & 682.19 & 0.331 & 0.23 & 0.101 & 130.68 & 20.7 & 8 \\
\hline
\end{tabular}

\subsection{Clopyralid adsorption on OSAC}

\subsubsection{Effect of mass catalyst}

Olive Stones Activated Carbon concentration effect was tested in the range of 0.1 to $1 \mathrm{~g} \mathrm{~L}^{-1}$. The degradation rate of clopyralid regardless of the amount of catalyst used extent versus time for the particles sizes $(0.2-0.5 \mathrm{~mm})$ at clopyralid initial concentration $(1 \mathrm{ppm})$ and natural $\mathrm{pH}$ are depicts in Figure 2. As observed from this figure, the adsorption of clopyralid is rapid initially and the uptake of clopyralid increases from 30 to $90 \%$ with increasing amount added of OSAC from 0.1 to $1 \mathrm{~g} \mathrm{~L}^{-1}$. An increase in adsorption with the catalyst dosage can be attributed to greater surface area and the availability of more adsorption sites. Although the adsorbed amount increases with adsorbent concentration, this increase is not linear. The clopyralid removal using $0.1 \mathrm{~g}$ of catalyst was only $30 \%$ in 3 hours. In the range 0.5 to 1 g. $\mathrm{L}^{-1}$, a slight increase of the efficiency can be envisaged, beyond $0.5 \mathrm{~g} . \mathrm{l}^{-1}$ there is no considerable effect on the clopyralid amount adsorbed indicating that $0.5 \mathrm{~g} \mathrm{~L}^{-1}$ of OSAC is sufficient for the optimum removal of of clopyralid. Therefore dosage of adsorbent was selected as $0.5 \mathrm{~g} \mathrm{~L}^{-1}$ for all experimental studies.

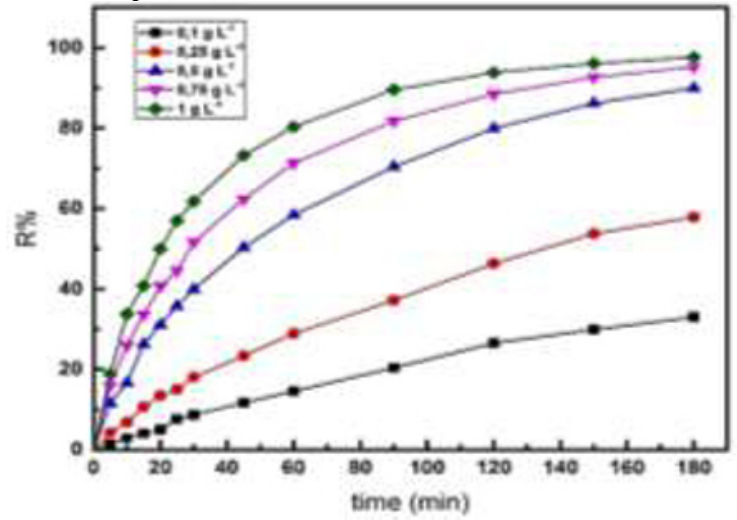

Fig. 2. Adsorption of Clopyralid at different concen-tration $\left(0.1-1 \mathrm{~g} \mathrm{~L}^{-1}\right) . \mathrm{V}=0.5 \mathrm{~L}, \mathrm{pH}=5.0 ; \mathrm{C}_{\text {clop }}=1 \mathrm{ppm}$.

\subsubsection{Adsorption kinetics}

The kinetic adsorption data was applied to describe the mechanism of adsorption process in terms of the order of rate constant. The kinetic is fitted with the pseudo-firstorder [27], pseudo second- order [28] and Weber and Morris based on intra particular diffusion [29] models.

In order to obtain the rate constants, the straight line plots of $\operatorname{Ln}\left(\mathrm{q}_{\mathrm{e}^{-}} \mathrm{q}_{\mathrm{t}}\right)$ and $\mathrm{t} / \mathrm{q}_{\mathrm{t}}$ against $\mathrm{t}$ depicted in Figure 3 has been analyzed. The rate constants, $\mathrm{k}_{1}, \mathrm{k}_{2}$ and correlation coefficients, $\mathrm{R}^{2}$, values of the clopyralid adsorption on OSAC were calculated from plots. The kinetic parameters $\left(\mathrm{q}_{\mathrm{e}}, \mathrm{k}_{1}, \mathrm{k}_{2}\right.$ and $\left.\mathrm{R}^{2}\right)$ of these models are illustrated in table 3..Results are agree with the experimental data except for the low concentration $(0.1 \mathrm{~g}$ $\left.\mathrm{L}^{-1}\right)$ the calculated $q \mathrm{e}$ is very higher than experimental $q e$.

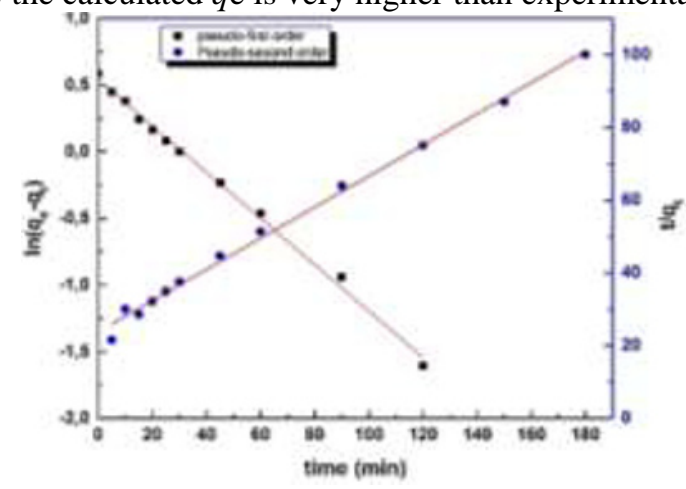

Fig. 3. Pseudo-first-order and pseudo-second-order kinetic model plots for adsorption of clopyralid onto OSAC $\left(0.5 \mathrm{~g} . \mathrm{L}^{-1}\right)$

For the pseudo-second-order kinetic model $\left(\mathrm{R}^{2}>0.98\right)$ and the calculated qe values agree very well with the experimental data. This confirm that the adsorption of clopyralid obey the second order kinetic model.

\subsection{Degradation of clopyralid using diverse catalytic processes}

\subsubsection{Clopyralid degradation and mineralization}

Some experimental series were conducted to assess the efficacy of various AOPs on both, clopyralid and the corresponding degree of mineralization in terms of total organic carbon elimination. The oxidation systems applied were ozonation $\left(\mathrm{O}_{3}\right)$, catalytic ozonation $\left(\mathrm{O}_{3} /\right.$ OSAC $)$, Photolytic ozonation $\left(\mathrm{O}_{3} /\right.$ Daylight $)$ and Photo catalytic ozonation in the presence of activated carbon $\left(\mathrm{O}_{3} / \mathrm{OSAC} /\right.$ Daylight $)$. Figure 4 reveals the concentration profiles during the course of these experiments for clopyralid degradation. Ozonation of clopyralid requires almost 3 hours to reduce its concentration above $90 \%$ while in the case of $\mathrm{O}_{3} /$ Daylight and $\mathrm{O}_{3} / \mathrm{OSAC}$ systems the reaction is very faster, showing conversions $80 \%$ and $85 \%$ in roughly $30 \mathrm{~min}$, respectively. The application of $\mathrm{O}_{3} / \mathrm{OSAC} /$ Daylight system led to a complete removal of compound in only 30 min of reaction time. These results demonstrate that in these processes clopyralid is mainly degraded by the action of hydroxyl radicals generated after ozone decomposition. Moreover, all experiments were started to 
assess the effect of different processes on the TOC abatement rate of clopyralid after $180 \mathrm{~min}$ of treatment. Figure 5 shows that single ozonation led to mineralization percentage of $20 \%$. While, $66 \%$ of TOC removal was achieved by $\left(\mathrm{O}_{3} / \mathrm{OSAC}\right)$. Photo-ozonation systems (presence of radiation) both in the absence and presence of catalyst $\mathrm{O}_{3}$ /Daylight and $\mathrm{O}_{3} / \mathrm{OSAC} /$ Daylight, respectively, led to enhancement of the clopyralid mineralization rates, which $90 \%$ TOC removal was achieved in these processes. For instance, single ozonation did not lead to significant mineralization, ozonation efficiency is affected by the accumulation of refractory products while their combination with activated carbon and solar radiation allowed a great TOC removal. These results suggest that, ozone decomposition in aqueous solution generate free radical leading to the partial mineralization.

However, a high concentration of free radicals is needed to achieve total clopyralid depletion and degrade their intermediates, thus reached a high level of clopyralid mineralization. These radicals are likely due to the main responsible species for the clopyralid mineralization.

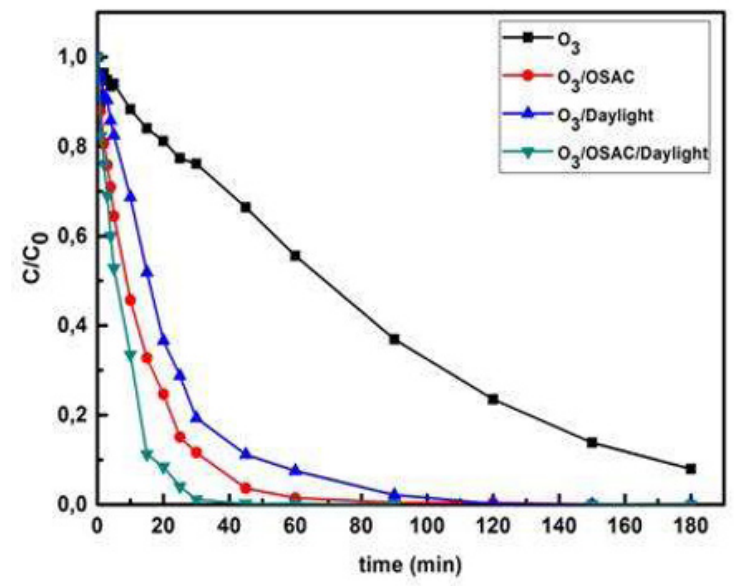

Fig. 4. Time-evolution of clopyralid removal using different systems. Experimental conditions: $\mathrm{V}=0.5 \mathrm{~L} ; \mathrm{pH}=5.0$; $\mathrm{C}_{\text {clopyralid }}=10 \mathrm{mg} \mathrm{L}^{-1}, \mathrm{Q}_{\mathrm{Gas}}=30 \mathrm{~L} \mathrm{~h}^{-1} ; \mathrm{C}_{\mathrm{O} 3 \mathrm{in}}=15 \mathrm{mg} \mathrm{L}^{-1}$; initial $\mathrm{OSAC}=0.5 \mathrm{~g} \mathrm{~L}^{-1}$

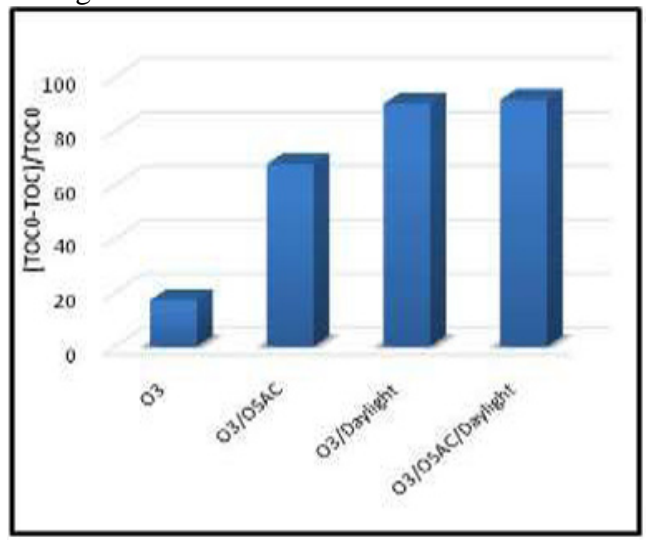

Fig. 5. Evolution of normalized TOC using different technologies of clopyralid degradation. Experimental conditions: $\mathrm{V}=0.5 \mathrm{~L} ; \mathrm{pH}=5.0 ; \mathrm{C}_{\text {clopyralid }}=10 \mathrm{mg} \mathrm{L}^{-1}, \mathrm{Q}_{\mathrm{Gas}}=30 \mathrm{~L} \mathrm{~h}^{-1} ; \mathrm{C}_{\mathrm{O} \text { in }}$ $=15 \mathrm{mg} \mathrm{L}^{-1}$; initial OSAC $=0.5 \mathrm{~g} \mathrm{~L}^{-1}$.

\subsubsection{Kinetic study}

The kinetic evaluation of the clopyralid degradation processes was carried out. The coupling process may involve the calculation of the synergy in term of clopyralid degradation rates. The pseudo-first-order kinetics can be utilized, to calculate the degradation rate for the decomposition of clopyralid by using the following equations:

$$
\begin{aligned}
& \text { Clopyralid }+\mathrm{O}_{3} \rightarrow \text { products } \\
& -\frac{d C_{\mathrm{Clo}}}{d t}=k_{\mathrm{O}_{3}} C_{\mathrm{Clo} \mathrm{O}_{3}}+k_{\mathrm{OH}^{\circ}} C_{\mathrm{OH}^{\circ}} C_{\mathrm{Clo}} \\
& -\frac{d C_{\mathrm{Clo}}}{d t}=k_{o b s} C_{\mathrm{Clo}} \\
& k_{o b s}=k_{\mathrm{O}_{3}} C_{\mathrm{O}_{3}}^{m}+k_{\mathrm{OH}^{\circ}} C_{\mathrm{OH}^{\circ}}
\end{aligned}
$$

Where $\mathrm{k}_{\mathrm{O} 3}$ and $\mathrm{k}_{\mathrm{OH}^{\circ}}$ are the kinetic oxidation constants of direct and indirect reaction respectively $\left(\mathrm{min}^{-1}\right), \mathrm{C}_{\mathrm{Clo}}$ is the concentration of clopyralid, $\mathrm{C}_{\mathrm{O} 3}$ is the concentration of dissolved ozone $\left(\mathrm{mg} \mathrm{L}^{-1}\right),(\mathrm{m}=1)$ the kinetic order reaction with respect to $\mathrm{O}_{3}$ and $\mathrm{t}$ is time (min), $\mathrm{k}_{\mathrm{obs}}$ is a kinetic constant reaction depending on temperature and $\mathrm{pH}\left(\mathrm{min}^{-1}\right)$.After integration:

$$
\ln \frac{C_{C l o, 0}}{C_{C l o}}=K_{o b s} . t
$$

The rate constant for each applied process are the apparent pseudo first order constants for clopyralid depletion calculated from the data plotted in figure 6 . The curves are plotted from $180 \mathrm{~min}$ when all the parent compounds had already been removed and only refractory by products persisted, whose concentration slowly decreased with time. The slope of each curve, defined here as rate constant. Values of fitting results are illustrated in Table 4, $\mathrm{k}_{\mathrm{obs}}$ were found to be $0.01 \mathrm{~min}^{-1}$, $0.041 \mathrm{~min}^{-1}, 0.0705 \mathrm{~min}^{-1}$ and $0.1433 \mathrm{~min}^{-1}$ for $\mathrm{O}_{3}, \mathrm{O}_{3}$ in the presence of solar radiation $\left(\mathrm{O}_{3} /\right.$ Daylight $), \mathrm{O}_{3}$ in the presence of OSAC $\mathrm{O}_{3} / \mathrm{OSAC}$ and $\mathrm{O}_{3} / \mathrm{AC} /$ Daylight ,respectively.

In these conditions, the combined process allows a very significant enhancement in the kinetics of degradation pollutant compared to the required ozone rate. Thus, this coupling is of great interest when the kinetics of ozonation in the liquid phase is slow. Synergism percentage was calculated using the following equation:

$$
\Lambda_{\text {syyergism }}=\frac{k_{O_{3} / \text { OSACIDayyight }}-\left[k_{O_{3}}+k_{O_{3} / \text { OSAC }}+k_{O_{3} / \text { Daylight }}\right]}{k_{O_{3} / \text { OSACIDayight }}} \times 100
$$

Where $\mathrm{k}_{\mathrm{O} 3}, \mathrm{k}_{\mathrm{O} 3 / \mathrm{OSAC}}, \mathrm{k}_{\mathrm{O} 3 / \text { Daylight }}$ and $\mathrm{k}_{\mathrm{O} 3 / \mathrm{OSAC} / \text { Daylight, }}$ are empirical pseudo first order rate constants corresponding to $\mathrm{O}_{3}, \mathrm{O}_{3} / \mathrm{OSAC}, \mathrm{O}_{3} /$ Daylight and $\mathrm{O}_{3} / \mathrm{OSAC} /$ Daylight, respectively. Synergism percentage was calculated to be $15.12 \%$. Hence, $\mathrm{O}_{3} / \mathrm{OSAC} /$ Daylight cannot be explained as the sum of $\mathrm{O}_{3}, \mathrm{O}_{3} / \mathrm{OSAC}$, and $\mathrm{O}_{3} /$ Daylight. 
Table 4. Experimental determination of rate kinetics constants of clopyralid degradation by different processes

\begin{tabular}{lllll} 
Process & $\mathbf{O}_{\mathbf{3}}$ & $\mathbf{O}_{\mathbf{3}}$ /Daylight & $\mathbf{O}_{\mathbf{3}} /$ OSAC & $\begin{array}{l}\mathbf{O}_{3} / \text { OSAC/ } \\
\text { Daylight }\end{array}$ \\
\hline $\begin{array}{l}\mathbf{k}_{\text {obsl }}\left(\mathbf{m i n}^{-}\right. \\
\mathbf{1}^{-}\end{array}$ & 0.01 & 0.041 & 0.0705 & 0.1433 \\
\hline $\mathbf{R}^{\mathbf{2}}$ & 0.986, & 0.9887 & 0.9989 & 0.9915 \\
\hline
\end{tabular}

\section{Conclusion}

Photo-ozonation by solar radiation combined with activated carbon can lead to the complete oxydation of the cloyralid, it has a powerful capacity of generating hydroxyls radicals enhances their mineralization rate. Although, single ozonation does not lead to a significant mineralization. Hence, the application of ozonation and OSAC leads to an improvement of the mineralization degree. In this work, the adsorption capacity of activated carbon was evaluated clopyralid adsorbent increased with increasing amount of catalyst. The fitting of experimental data to apparent pseudo first order reaction models let clopyralid concentration conversion kinetics to be simulated for the oxidation technologies studied. Furthermore, activated carbon adsorbent can be regenerated and reused after clopyralid treatment. The kinetic experiments were examined by different models, that the pseudo second order kinetic equation was the best to describe adsorption process.

\section{References}

1. Templeton M. R., Graham N. J. D., Martijn B. J., Royce A., \& Kruithof J. C. Low pressure UV/ $\mathrm{H}_{2} \mathrm{O}_{2}$ treatment for the degradation of the pesticides metaldehyde, clopyralid and mecoprop e Kinetics and reaction product formation, 91, 285-294 (2016).

2. Solís R. R., Rivas F. J., Gimeno O. Applied Catalysis B : Environmental Removal of aqueous metazachlor, tembotrione, tritosulfuron and ethofumesate by heterogeneous monopersulfate decomposition on lanthanum-cobalt perovskites. "Applied Catalysis B, Environmental, ’200, 83-92 (2017).

3. Xu G., Bu T., Wu M. Electron beam induced degradation of clopyralid in aqueous solutions, 759764 (2011).

4. Vidales M. J. M., Castro M. P., Sáez C., Cañizares P., \& Rodrigo M. A. Irradiated-assisted electrochemical processes in semi-pilot scale for the removal of clopyralid from soil washing wastes. Separation and Purification Technology (2018).
5. Rodriguez M., Muñoz-morales M., Pérez J. F., Saez, C., Ca, P., Eduardo C., Rodrigo M. A. Towards the development of efficient electro-Fenton reactors for soil washing wastes through microfluidic cells towards the development of efficient electro-Fenton reactors for soil washing wastes through microfluidic cells(2018).

6. Özcan A., Oturan N., Yücel Ş., Oturan M. A. (n.d.). International Journal of Environmental ElectroFenton treatment of aqueous Clopyralid solutions, 37-41(2014).

7. Tizaoui C., Mezughi K. and Bickley R., Heterogeneous photocatalytic removal of the herbicide clopyralid and its comparison with $\mathrm{UV} / \mathrm{H}_{2} \mathrm{O}_{2}$ and ozone oxidation techniques, Desalination 273:197-204, (2011).

8. Sáez C., Cañizares P., \& Rodrigo M. A. Electrochemistry Communications a new strategy for the electrolytic removal of organics based on adsorption onto granular activated carbon. Electrochemistry Communications, 90, 47-50(2018).

9. Anderluh V. B., Oř D. Z., Abramovi B. F., \&Soji, D. V. Photodegradation of clopyralid in $\mathrm{TiO} 2$ suspensions: Identification of intermediates and reaction pathways, 168, 94-101 (2009).

10. Berberidou C., Kitsiou V., Karahanidou S., Lambropoulou D. A., Kouras A., Kosma C. I., Poulios, I. Photocatalytic degradation of the herbicide clopyralid : kinetics, degradation pathways and ecotoxicity evaluation, (2015).

11. Orellana-garcía F., Álvarez, M. A., López-ramón, V., Rivera-utrilla J., Sánchez-polo M., \&Mota, A. J. Photodegradation of herbicides with different chemical natures in aqueous solution by ultraviolet radiation. Effects of operational variables and solution chemistry, 255, 307-315(2014).

12. Hassani A., Khataee A., Fathinia M., \&Karaca S. PT SC. Process Safety and Environmental Protection (2018).

13. Ozcan A., \&Gençten M. Chemosphere Investigation of acid red 88 oxidation in water by means of electroFenton method for water purification, 146, 245-252 (2016).

14. Carboneras M. B., Cañizares P., Rodrigo M. A., \& Fernandez-morales F. J. Improving biodegradability of soil washing effluents using anodic oxidation. Bioresource Technology (2017).

15. Rodríguez E. M., Márquez G., León, E. A., Álvarez P. M., Amat A. M., \&Beltrán F. J. Mechanism considerations for photocatalytic oxidation, ozonation and photocatalytic ozonation of some pharmaceutical compounds in water. Journal of Environmental Management, 127, 114-124 (2013).

16. Sans C., \&Esplugas S. Priority pesticide dichlorvos removal from water by ozonation process: reactivity, transformation products and associated toxicity. Separation and Purification Technology (2017). 
17. Farines V., Baig S., Albet J., Molinier J., \&Legay C. Ozone transfer from gas to water in a co-current upflow packed bed reactor containing silica gel, 91, 67-73(2003).

18. Demir F., \&Atguden A. Experimental Investigation on the Microbial Inactivation of Domestic Well Drinking Water using Ozone under Different Treatment Conditions Experimental Investigation on the Microbial Inactivation of Domestic Well Drinking Water using Ozone under Different Treatment Conditions, 9512 (2016).

19. Solís,R. R., Rivas F. J., FerreiraL. C., Pirra A., Toxic I Hazardous Substances and Environmental Engineering Integrated aerobic biological - chemical treatment of winery wastewater diluted with urban wastewater. LED-based photocatalysis in the presence of monoperoxysulfate, 4529 (2017).

20. Tizaoui C., \&Grima N. Kinetics of the ozone oxidation of Reactive Orange 16 azo-dye in aqueous solution. Chemical Engineering Journal, 173(2), 463-473 (2011).

21. TangtaoYa Junmin Pe, Yun Zh, Xuan He, YidongHou, Ling $\mathrm{Wu}$, Xianzhi $\mathrm{Fu}$, Enhanced photocatalytic ozonation degradation of organic pollutants by $\mathrm{ZnO}$ modified $\mathrm{TiO} 2$ nanocomposites, Applied Catalysis B: Environmental, (2017).

22. Sevilla-morán B., Mateo-miranda M. M., \& José, L. (n.d.). Sunlight transformation of sethoxydimlithium in natural waters and effect of humic acids, International Journal of Environmental 37-41(2014).

23. José J., Sevilla-morán B., López-goti, C., Calvo, L., Alonso-prados, J. L., \&Sandín-españa, P. Science of the Total Environment Photolysis of clethodim herbicide and a formulation in aquatic environments :
Fate and ecotoxicity assessment of photoproducts by QSAR models. Science of the Total Environment, 615, 643-651(2018).

24. S. Najar, A. Ouederni, and A. Ratel, Activated carbon from olive stones by a two step process: influence of production parameters on textural characteristics, Annales de Chimie Science des Matériaux31: 151-167, (2006).

25. Rivera-Utrilla.J, Bautista-Toledo.I, Ferro- García. M.A, Moreno- Castilla. C, Activated carbon surface modifications by adsorption of bacteria and their effect on aqueous lead adsorption, J. Chem. Technol. Biotechnol., 76:1209-1215, 2001.

26. John L, Gennady Yu. Gor, Alexander V. Neimark, Density functional theory methods for characterization of porous materials, Colloids and Surfaces A: Physicochem. Eng. Aspects 437:3- 32, (2013).

27. Tan I. A. W., Hameed B. H., \& Ahmad A. L. Equilibrium and kinetic studies on basic dye adsorption by oil palm fibre activated carbon, 127, 111-119 (2007).

28. Malik P. K. Dye removal from wastewater using activated carbon developed from sawdust : adsorption equilibrium and kinetics, 113, 8188(2004).https://doi.org/10.1016/j.jhazmat.2004.05.0 22

29. Srihari, V., \& Das, A. The kinetic and thermodynamic studies of phenol-sorption onto three agro-based carbons, 225, 220-234(2008).

30. Liu, Q., Zheng, T., Wang, P., Jiang, J., \& Li, N. Adsorption isotherm, kinetic and mechanism studies of some substituted phenols on activated carbon fibers, 348-356(2010) 